Old Dominion University ODU Digital Commons

Educational Foundations \& Leadership Faculty

Publications

Educational Foundations \& Leadership

9-2018

\title{
When Internationalization Funding Feels Tight: Satisfaction With Funding and Campus Internationalization Strategies
}

Chris R. Glass

Old Dominion University

Jenny J. Lee

Follow this and additional works at: https://digitalcommons.odu.edu/efl_fac_pubs

Part of the Educational Assessment, Evaluation, and Research Commons, and the Higher Education Commons

\section{Repository Citation}

Glass, Chris R. and Lee, Jenny J., "When Internationalization Funding Feels Tight: Satisfaction With Funding and Campus Internationalization Strategies" (2018). Educational Foundations \& Leadership Faculty Publications. 51.

https://digitalcommons.odu.edu/efl_fac_pubs/51

\section{Original Publication Citation}

Glass, C. R., \& Lee, J. J. (2018). When internationalization funding feels tight: Satisfaction with funding and campus

internationalization strategies. Journal of Studies in International Education, 22(4), 302-316. doi:10.1177/1028315318773146

This Article is brought to you for free and open access by the Educational Foundations \& Leadership at ODU Digital Commons. It has been accepted for inclusion in Educational Foundations \& Leadership Faculty Publications by an authorized administrator of ODU Digital Commons. For more information, please contact digitalcommons@odu.edu. 
When Internationalization Funding Feels Tight: Satisfaction With Funding and Campus Internationalization Strategies
Journal of Studies in International Education 2018, Vol. 22(4) 302-316

(C) 2018 European Association for International Education Reprints and permissions: sagepub.com/journalsPermissions.nav DOI: |0.II77/|0283|53|8773|46 journals.sagepub.com/home/jsi

\author{
Chris R. Glass' and Jenny J. Lee ${ }^{2}$
}

\begin{abstract}
This study investigated predictors of satisfaction with an institution's strategy for campus internationalization among international affairs staff $(N=1,520)$ and compared the varying perceptions of their institution's funding to fulfill this mandate. This study identified factors that influenced these individuals' sense of their institution's internationalization strategy. Among international affairs staff who were most dissatisfied with their institution's funding, satisfaction with how their institution managed the outsourcing of university functions, and perceived competition with other universities most influenced their perceptions of strategy. For those moderately satisfied with funding, retention of senior university leadership most influenced their perceptions of strategy. Support from senior administration, communication with faculty, and capacity to support increased student enrollment influenced perceptions of strategy for all respondents. The results of this study suggest the negotiation of the educational and entrepreneurial rationales for internationalization are far more complex - and dependent on far more factors - at institutions where international affairs staff perceive fewer human and financial resources to be available.
\end{abstract}

\title{
Keywords
}

strategic institutional management of internationalization, internationalization of higher education, university staff satisfaction, comprehensive internationalization, globalization and international higher education

'Old Dominion University, Norfolk, VA, USA

${ }^{2}$ University of Arizona, Tucson, AZ, USA

\section{Corresponding Author:}

Chris R. Glass, Old Dominion University, I66-I Education Building, 5 II 5 Hampton Blvd., Norfolk, VA 23510, USA.

Email: crglass@odu.edu 
Following a record high count of over a million international students in the United States (Institute for International Education [IIE], 2016), almost 40\% of U.S. colleges and universities experienced a decline of international student applications (American Association of Collegiate Registrars and Admissions Officers [AACRAO], 2017), following President Trump's travel ban against many Muslim-majority countries and increasing anti-immigrant perceptions in the United States (Lee, 2017). The executive orders and negative public sentiments have had a chilling effect on global perceptions of the United States. Consequently, institutional leaders are grappling with a potentially sizable decline in enrollment revenue, more than half of the increased revenue for some universities (Bound, Braga, Khanna, \& Turner, 2016) as international students may be seeking study elsewhere (Redden, 2017). Internationalization in U.S. universities, which was largely fueled by high global demand, now requires new strategies to maintain their global presence and, perhaps, their economic survival.

Such dependency on external resources to sustain university operations and advance internationalization is not new, but has become particularly acute due to the ongoing decrease of public funds, increasing global demand for international study, and intensifying competition among universities for resources (e.g., students, faculty, grants, etc.) Due to the substantial revenue that international students generate to offset other financial shortfalls, internationalization in higher education has been increasingly scrutinized as a form of privatization, in which international students are largely valued for their economic benefits (Slaughter \& Cantwell, 2011). Research highlights evidence of an increasing number of entrepreneurial activities, including international student recruitment and international alumni donation solicitations, and study abroad expansion (Cantwell, 2015; Deschamps \& Lee, 2015). Such institutional behaviors have been proposed as a form of resource dependency in seeking new streams of funds to replace state subsidies but carries consequences of reshaping the rationales and strategies of an organization (Pfeffer \& Salancik, 1978). For such reasons, entrepreneurialism has been described as a key driver of international education (Altbach \& Knight, 2007).

All organizations manage human and financial dependences as part of their institution's strategy for internationalization (Green, Marmolejo, \& Egron-Polak, 2012); however, some institutions are simply more vulnerable to fluctuations in their fiscal environment than others. For example, when state appropriations decline, public universities that do not have a history of enrolling large numbers of out-of-state students become more reliant on international student enrollment for revenue generation compared with universities that more easily attract out-of-state students (Bound et al., 2016). Overall, revenue generation has become a top priority in the internationalization of U.S. campuses, according to the most recent Mapping Internationalization on U.S. Campuses Survey (American Council on Education [ACE], 2012). Therefore, institutions with more financial dependencies on internationalization may increase revenue-generating forms of internationalization alongside traditional forms of international educational and exchange.

Qualitative research of senior internationalization officers (SIOs) has identified activities that reflect revenue-generating motivations (Deschamps \& Lee, 2015). As 
economic conditions change, the international office of the institution adapts to better align with the fiscal environment. Behaviors of international affairs staff vary by perceptions of resources in institutions as resource dependency theory emphasizes that organizational behavior is influenced through the allocation of resources (Casciaro \& Piskorski, 2005).

There is little research on the perceptions of international affairs staff (Deschamps $\&$ Lee, 2015) but more empirical research is necessary given the central role these individuals play in internationalization efforts. Less organizational behavior research has been conducted with stakeholders beyond SIOs to include international affairs staff who work in education abroad, international enrollment, and international student and scholar services. Thus, as an extension to Deschamps and Lee's (2015) past research on SIOs, we investigated the coexistence of various institutional strategies for internationalization through our proposed Mergers, Acquisitions, and Executive Succession framework among more diverse international affairs staff. Based on Deschamps and Lee's (2015) study, mergers refer to "programs that simultaneously benefit either partnering institutions or countries" and acquisitions are "activities focused on the acquiring of resources from abroad" (p. 132). To further Deschamps and Lee's (2015) framework, we propose the concept of executive succession, which, according to Pfeffer and Salancik (1978), refers to "strategic response to environmental contingencies." While the mergers and acquisitions refer to deliberate, proactive strategies, executive succession as a response to economic uncertainty. Through this more comprehensive framework, we asked, "What are the merger, acquisition, and executive succession factors that influence satisfaction with internationalization strategy? How do they compare across individuals with low-, moderate-, and high-levels of satisfaction with funding for internationalization at their institution?"

\section{Conceptual Framework}

Resource dependence theory (RDT) examines how external resources affect organizational behavior (Pfeffer, 1987; Pfeffer \& Salancik, 1978). The key aspect of RDT related to this study is that "organizations take actions to manage external interdependencies" (Pfeffer, 1987, p. 27). As RDT relates to the current study, international educators advance internationalization in environments characterized by human and financial dependences with other organizations. RDT is one way to empirically examine how international affairs offices have become more entrepreneurial in recent years. For example, a decline in state appropriations has led U.S. universities to implement strategies rationalized as benefiting all parties while also potentially generating revenue for the university. RDT provides a well-established empirical framework to understand entrepreneurial organizational behaviors associated with comprehensive internationalization.

In line with a focus on resource dependency, Deschamps and Lee (2015) observed an increase of entrepreneurial activities among SIOs and proposed a framework of mergers and acquisitions in describing how they managed human and financial dependences with other organizations. In their typology, Merger strategies refer to "programs that simultaneously benefit either partnering institutions or countries" (Deschamps \& 
Lee, 2015, p. 12). Examples of merger activities included partnerships which included dual degree programs and overseas educational delivery, which were rationalized as benefiting all parties while also potentially generating revenue. Acquisition strategies refer to "activities focused on the acquiring of resources from abroad" (Deschamps \& Lee, 2015, p. 10). Examples of acquisition activities included increased interest in international student recruitment and targeted international alumni fundraising, which were activities directly intended to generate university revenue. In this study, we added a third strategy, executive succession, which RDT research has found to be a "strategic response to environmental contingencies" (Pfeffer \& Salancik, 1978, p. 248). Unlike the external nature of mergers and acquisitions, executive succession strategies refer to internal activities designed to mitigate executive turnover through professional development, retention, and advancement strategies. Executive succession is particularly important in a resource scarce environment, as noted by Welsh and Dehler (1988) who argue that "with scarce resources, the impact of a successor's actions will be much less ambiguous than it will be when resources are abundant" (p. 949). Executive succession planning promotes intraorganizational trust that reduces uncertainty in an unpredictable environment (Glass \& Matherly, 2015).

We now outline the Mergers, Acquisitions, and Executive Succession conceptual framework in more detail: In this study, we were interested in factors that influence international educators' satisfaction with internationalization strategy. We focus on three types of factors (i.e., merger, acquisition, and executive succession) that universities may exhibit in efforts to manage organizational interdependencies at institutions where international educators perceive internationalization as differently resourced. As Deschamps and Lee (2015) observed, “. . . many differences exist between international offices on different campuses. The internal and external environments of an HEI (higher education institution) affect where the international office exists within the HEI and how it fulfills its responsibilities" (p. 7). Because international educators enact these strategies, they were the focus of this research study.

As RDT emphasizes intra- and interorganizational dependences, we examined international educators' perceptions of organizational behavior (Hillman, Withers, \& Collins, 2009), comparing international educators who perceive funding for internationalization at their institution as low, moderate, or high. First, we were interested in examining international educators' perceptions of merger organizational behaviors, including their satisfaction with interorganizational dependencies (e.g., outsourcing of university functions) and their perception of the relative strength of their organization within the market competing for financial and human resources (e.g., competition with other universities). Organizations must manage these interorganizational relationships in a way that strengthens their position among a society of organizations (Casciaro \& Piskorski, 2005; Hillman et al., 2009). In addition, we were interested in examining international educators' perceptions of acquisition behaviors, including acquisition of international student tuition and human resources (e.g., capacity to support increased international student enrollment, Hillman et al., 2009). Finally, we were interested in examining international educators' perceptions of executive succession organizational behaviors, including retention of key staff (e.g., retention of 
talented SIOs and international education staff and retention of senior university leadership), development of existing staff (e.g., opportunities for professional advancement within the university), structural supports (e.g., support from senior administration), and intraorganizational cohesion (e.g., communication with faculty and coordination of campus offices, Hillman et al., 2009). Importantly, we were not aware of any study that has examined the interrelationships among these strategies. This study has the potential to identify which environmental contingencies hold the most sway over entrepreneurial organizational behaviors, depending on perceptions of the extent of institutional resources.

For comprehensive internationalization efforts, multiple dependencies and strategies coexist. Educational (Knight, 2004) and entrepreneurial (Williams \& Kitaev, 2005) rationales for international education can be simultaneous. Consequently, international educators' satisfaction with perceptions of organizational strategy can serve as a proxy to negotiating coexisting goals of educational and entrepreneurial rationales for international education. Each of these three strategies outlined above reflects various degrees of risk and dependency; however, no large-scale study has been conducted that examines these dependences empirically. While Deschamps and Lee's (2015) study was limited to international offices from the perspective of SIOs, it is reasonable to assume such views are not only limited to this population but also extend to others involved in international education. Thus, we utilized the concepts of mergers, acquisitions, and executive succession to observe the extent to which such resource dependency was related to individuals' satisfaction with their institutional strategy.

\section{Method}

For campus internationalization to be comprehensive, it must also be strategic, taking into consideration institutional context and resources. This study examined predictors of satisfaction with the institution's strategy for campus internationalization and how they varied by respondents' perceptions of their institution's international funding.

\section{Research Questions and Hypotheses}

We examined the following question:

What are the merger, acquisition, and executive succession factors that influence satisfaction with internationalization strategy? How do they compare across individuals with low-, moderate-, and high-levels of satisfaction with funding for internationalization at their institution?

We used ordinal regression to examine how "organizations take actions to manage external interdependencies" with implications for how "patterns of dependence produce interorganizational as well as intraorganizational power" (Hillman et al., 2009, p. $1405)$ as it relates to internationalization with a comparison of universities where international educators perceive themselves to be in low, moderate, and high resourced 
environments, using satisfaction as a proxy for the extent resourced environments. Based on existing research, we hypothesized that well-resourced universities would have fewer dependencies, thus fewer factors that influence a respondent's satisfaction with their institution's strategy for internationalization. We hypothesized as follows:

Hypothesis 1: International educators who are dissatisfied with funding for internationalization, but are nonetheless satisfied with their institution's strategy for internationalization, will also be satisfied with merger organizational behaviors (e.g., outsourcing and competition), whereas this will not be a significant predictor of satisfaction for international educators with moderate- and high-levels of satisfaction with funding for internationalization.

Hypothesis 2: International educators who are dissatisfied or moderately satisfied with funding for internationalization, and who are nonetheless satisfied with their institution's strategy for internationalization, will be satisfied with executive succession organizational behaviors (e.g., retention of senior university leadership), whereas this will not be a significant predictor of satisfaction for international educators with high-levels of satisfaction with funding for internationalization.

Hypothesis 3: International educators at all institutions who are satisfied with their institution's strategy for internationalization will also be satisfied with support from senior administration.

We are interested in this question, in part, to better understand the factors that might influence international educators' sense of an institution's comprehensive internationalization strategy even when they perceive that they are in an institutional environment where there are limited institutional resources and structural supports to fulfill this mandate. Strategy and funding tend to go hand-in-hand, but we were curious about what matters when they do not. This study is significant for international educators and researchers because there is an increasing realization among institutions of the need to undertake a strategic approach to internationalization, but often this comes in an economic environment where typical funding streams may be insufficient to achieve significant progress.

\section{Participants}

Approximately 10,000 participants were recruited as part of a survey of international educators. Participants received an email inviting them to participate in the study. The email contained a unique link to the questionnaire to ensure no duplication of responses. In all, 1,520 international educators responded to the questionnaire. Respondents reported various roles in international education, including education abroad (19\%), international enrollment (13\%), international student and scholar services $(39 \%)$, senior international officers $(15 \%)$, and as faculty members $(3 \%)$ and other various positions (11\%). Fifty-one percent of the respondents were employed at doctoral granting universities, followed by master's college/university (19\%), baccalaureate colleges $(13 \%)$, associate's colleges $(7 \%)$, and special focus institutions $(9 \%)$. 
Respondents identified as female ( $72 \%)$, male (26\%), or preferred not to answer (2\%); they identified as Caucasian/White (72\%), Asian/Asian American (8\%), Hispanic (6\%), African American/Black (4\%), Middle Eastern (1\%), Non-White Hispanic $(1 \%)$, Native American/Alaskan Native $(<1 \%)$, Pacific Islander/Native Hawaiian $(<1 \%)$, or preferred not to answer $(7 \%)$.

Researchers dummy-coded a variable for subgroup analyses based on the respondent's response to the question, "Over the past 5 years, how satisfied or dissatisfied are you with maintaining funding for campus internationalization on your campus?" $(1=$ not at all satisfied to $5=$ extremely satisfied). Satisfaction with funding was utilized as a proxy to reflect perceptions of actual funding. Respondents who indicated they were not at all satisfied or slightly dissatisfied were dummy-coded in the low satisfaction group $(n=674)$, respondents who indicated they were moderately satisfied were dummy-coded in moderate satisfaction group $(n=402)$, respondents who indicated they were very satisfied or extremely satisfied were dummy-coded in high satisfaction group $(n=444)$. A chi-square analysis comparison between group demographics indicated that there were no significant differences between institution groups by respondents' institution type, gender, race/ethnicity, current position, or level of education.

\section{Measures}

Independent measures. All independent measures were assessed using responses to items based on the "Over the past 5 years, how satisfied or dissatisfied are you with the following on your campus." The items were categorized into acquisition, merger, and executive succession categories. The acquisition item included "capacity to support increased student enrollment" $(M=2.84, S D=1.195)$. Merger items included "outsourcing of university functions" $(M=2.70, S D=1.090)$ and "impact of competition with other universities" $(M=3.03, S D=1.034)$. Executive succession items included "retention of international education office staff" $(M=3.13, S D=1.277)$, "retention of senior university leadership" ( $M=3.00, S D=1.180)$, "support from senior administration" ( $M=3.10, S D=1.298)$, "opportunities for professional advancement" $(M=3.14$, $S D=1.270)$, "communication with faculty" $(M=3.28, S D=1.067)$, and "coordination with other campus offices" $(M=3.42, S D=1.106)$.

Dependent measure. The primary outcome measure was satisfaction with internationalization strategy. Satisfaction with internationalization strategy was assessed using a Likert-type scale item $(1=$ not at all satisfied to $5=$ extremely satisfied $)$ in response to the question, "Over the past 5 years, how satisfied or dissatisfied are you with strategy for campus internationalization on your campus?"

\section{Analysis of Data}

The research question was answered by conducting ordinal regression analysis (Agresti \& Finlay, 2009; Ott \& Longnecker, 2001) with satisfaction with internationalization strategy as the dependent variable and factors that influence satisfaction (e.g., support 
from senior leaders, retention of senior leaders, coordination with other campus offices, capacity to support increased student enrollment, etc.) as independent variables. Cox and Snell's (1989) pseudo $R^{2}$ was used to the calculate the variance accounted for by the ordinal regression model for all models.

\section{Results}

The first analysis examined factors that influenced satisfaction with internationalization strategy for all respondents. Overall, ordinal regression analysis of all respondents $(n=1,520)$ revealed five factors that influenced satisfaction with the campus' internationalization strategy $\chi^{2}(11)=281.615, p<.000$, explaining $49 \%$ of the variation, a large effect size. Support from senior administration $(\beta=.71, p<.000)$ had the largest influence by far, followed by retention of senior university leadership $(\beta=.35, p=$ $.001)$, communication with faculty $(\beta=.33, p=.001)$, impact of competition with other universities $(\beta=.26, p=.006)$, and outsourcing of university functions $(\beta=.24$, $p=.026)$.

The second analysis examined factors that influence satisfaction with internationalization across individuals with low-, moderate-, and high-levels of satisfaction with funding for internationalization at their institution.

\section{Group I: Low Satisfaction With Funding for Internationalization}

The ordinal regression analysis of respondents from respondents who were not at all satisfied or slightly dissatisfied $(n=674)$ with funding for internationalization at their institution revealed that almost all of the factors influenced satisfaction with the campus' internationalization strategy $\chi^{2}(11)=111.960, p<.000$, explaining $34 \%$ of the variation, a medium to large effect size. Retention of senior university leadership $(\beta=.21, p=.055)$, support from senior administration $(\beta=.34, p<.000)$, communication with faculty $(\beta=.26, p=.001)$, outsourcing of university functions $(\beta=.25, p=.055)$, and impact of competition with other universities $(\beta=.32, p=.007)$ predicted greater satisfaction with the campus' internationalization strategy after controlling for retention of international education office staff, opportunities for professional advancement, coordination with other campus offices, and capacity to support increased student enrollment. Table 1 reports estimates of effect size and $p$ values for the ordinal regression.

\section{Group 2: Moderate Satisfaction With Funding for Internationalization}

The ordinal regression analysis of respondents who were moderately satisfied $(n=402)$ with funding for internationalization at their institution revealed that three factors influenced satisfaction with the campus' internationalization strategy $\chi^{2}(11)=67.000, p<.000$, explaining $33 \%$ of the variation, a medium to large effect size. Retention of senior university leadership $(\beta=.43, p=.008)$, support from senior administration $(\beta=.33, p=.012)$, communication with faculty $(\beta=.25, p=.037)$ predicted greater satisfaction with the campus' internationalization strategy after controlling for retention of international education office staff, opportunities for professional advancement, coordination with other 
Table I. Results for Respondents With Low Satisfaction With Funding for Internationalization.

\begin{tabular}{|c|c|c|c|c|c|}
\hline & $\beta$ & SE & $p$ & $\begin{array}{l}\text { Lower } \\
\text { bound }\end{array}$ & $\begin{array}{l}\text { Upper } \\
\text { bound }\end{array}$ \\
\hline \multicolumn{6}{|l|}{ Executive succession } \\
\hline Retention of senior university leadership & .207 & .108 & .055 & -.005 & .418 \\
\hline Communication with faculty & .255 & .079 & .001 & .100 & .409 \\
\hline Coordination with other campus offices & .059 & .051 & .252 & -.042 & .159 \\
\hline Opportunities for professional advancement & -.013 & .077 & .868 & -.163 & .137 \\
\hline Retention of international education office staff & -.006 & .072 & .929 & -.147 & .134 \\
\hline Support from senior administration & .344 & .078 & .000 & .192 & .497 \\
\hline \multicolumn{6}{|l|}{ Acquisition } \\
\hline Capacity to support increased student enrollment & .110 & .127 & .386 & -.139 & .358 \\
\hline \multicolumn{6}{|l|}{ Merger } \\
\hline Impact of competition with other universities & .323 & .120 & .007 & .087 & .558 \\
\hline Outsourcing of university functions & .246 & .128 & .055 & -.005 & .498 \\
\hline
\end{tabular}

Table 2. Results for Respondents With Moderate Satisfaction With Funding for Internationalization.

\begin{tabular}{|c|c|c|c|c|c|}
\hline & $\beta$ & SE & $p$ & $\begin{array}{l}\text { Lower } \\
\text { bound }\end{array}$ & $\begin{array}{l}\text { Upper } \\
\text { bound }\end{array}$ \\
\hline \multicolumn{6}{|l|}{ Executive succession } \\
\hline Retention of senior university leadership & .429 & .163 & .008 & .110 & .748 \\
\hline Communication with faculty & .251 & .120 & .037 & .015 & .488 \\
\hline Retention of international education office staff & .164 & .117 & .160 & -.065 & .393 \\
\hline Opportunities for professional advancement & .118 & .112 & .289 & -.101 & .338 \\
\hline Coordination with other campus offices & -.021 & .075 & .774 & -.168 & .125 \\
\hline Support from senior administration & .328 & .130 & .012 & .073 & .583 \\
\hline \multicolumn{6}{|l|}{ Acquisition } \\
\hline Capacity to support increased student enrollment & .137 & .197 & .486 & -.249 & .524 \\
\hline \multicolumn{6}{|l|}{ Merger } \\
\hline Impact of competition with other universities & .133 & .189 & .483 & -.239 & .504 \\
\hline Outsourcing of university functions & .185 & .200 & .356 & -.208 & .578 \\
\hline
\end{tabular}

campus offices, capacity to support increased student enrollment, outsourcing of university functions, and impact of competition with other universities. Table 2 reports estimates of effect size and $p$ values for the ordinal regression.

\section{Group 3: High Satisfaction With Funding for Internationalization}

The ordinal regression analysis of respondents who were very satisfied or extremely satisfied $(n=444)$ with funding for internationalization at their institution revealed 
Table 3. Results for Respondents With High Satisfaction With Funding for Internationalization.

\begin{tabular}{|c|c|c|c|c|c|}
\hline & $\beta$ & SE & $p$ & $\begin{array}{l}\text { Lower } \\
\text { bound }\end{array}$ & $\begin{array}{l}\text { Upper } \\
\text { bound }\end{array}$ \\
\hline \multicolumn{6}{|l|}{ Executive succession } \\
\hline Retention of senior university leadership & .120 & .137 & .382 & -.149 & .389 \\
\hline Communication with faculty & .088 & .116 & .446 & -.139 & .315 \\
\hline Retention of international education office staff & .058 & .099 & .558 & -.135 & .251 \\
\hline Opportunities for professional advancement & .065 & .097 & .501 & -.125 & .255 \\
\hline Coordination with other campus offices & .038 & .068 & .574 & -.095 & .172 \\
\hline Support from senior administration & .296 & .114 & .009 & .073 & .519 \\
\hline \multicolumn{6}{|l|}{ Acquisition } \\
\hline Capacity to support increased student enrollment & .196 & .161 & .223 & -.119 & .510 \\
\hline \multicolumn{6}{|l|}{ Merger } \\
\hline Outsourcing of university functions & -.067 & .160 & .675 & -.380 & .246 \\
\hline Impact of competition with other universities & .183 & .158 & .245 & -.126 & .493 \\
\hline
\end{tabular}

that only a single factor influenced satisfaction with the campus' internationalization strategy $\chi^{2}(11)=48.943, p<.000$, explaining $22 \%$ of the variation, a medium effect size. Support from senior administration $(\beta=.30, p=.009)$ predicted greater satisfaction with the campus' internationalization strategy after controlling for all other factors. Table 3 reports estimates of effect size and $p$ values for the ordinal regression.

\section{Discussion}

Entrepreneurialism is a key driver of international education at all types of institutions (Altbach \& Knight, 2007); however, as expected, significant differences existed in the merger, acquisition, and executive succession factors that influenced satisfaction with internationalization strategy. This study used the Mergers, Acquisitions, and Executive Succession conceptual framework to examine factors that influence satisfaction with internationalization strategy for international educators with low-, moderate-, and high-levels of satisfaction with funding for internationalization on their campus. In this section, we discuss the relationship between the hypotheses, framework, and actions organizations may take to manage external interdependencies. We pay particular attention to important differences from respondents who perceive themselves to work within environments with different levels of institutional resources and then discuss implications for policy and research in international higher education. We use RDT as a lens by which to interpret the strategies that institutions use to reduce environmental dependency (Hillman et al., 2009; Pfeffer \& Salancik, 1978), and we explore implications for how patterns of dependence at institutions with different level of human and organizational resources impact the satisfaction with the institution's strategy for internationalization. 
The results of this study support previous research that indicates that "many differences exist between international offices on different campuses. The internal and external environments of an HEI affect where the international office exists within the HEI and how it fulfills its responsibilities" (Deschamps \& Lee, 2015, p. 7). The results supported the first hypothesis: International educators who were dissatisfied with funding for internationalization, but were nonetheless satisfied with their institution's strategy for internationalization, were satisfied with merger organizational behaviors, such as how their institution outsourced university functions and the relative strength of their institution within a competitive marketplace. As expected, merger factors were not significant for respondents with greater satisfaction about funding for internationalization. The results supported the second hypothesis: International educators who were dissatisfied or moderately satisfied with funding for internationalization, but were nonetheless satisfied with their institution's strategy for internationalization, were satisfied with their institution's strategy for executive succession. The results also supported the third hypothesis: Support of senior administration was associated with satisfaction with the institution's strategy for internationalization for respondents in all three groups. We relate these three observations to the results and then discuss the implications of these results for policy and research.

First, respondents who were dissatisfied with funding for internationalization, but were nonetheless satisfied with their institution's strategy for internationalization, were the only group where merger organizational behaviors had a significant relationship with a sense of strategy for internationalization. This result does not indicate that participants were satisfied with merger organizational behaviors (e.g., outsourcing and competition) per se. On the contrary, outsourcing and competition were among the factors for which participants reported the least satisfaction. Rather, the support of the first hypothesis reinforces the insight from our framework that low-resourced institutions have far more external dependencies and, therefore, are far more sensitive to the nature of these dependencies. In other words, the only condition under which participants at low-resourced institutions expressed satisfaction was if they also perceived that outsourced dependencies were effectively managed. Likewise, it is not a surprise that respondents who were dissatisfied with funding for internationalization also cited the most number of - and greatest variety of - factors that impacted their satisfaction with the institution's strategy with internationalization. Internationalization involved navigating a myriad of merger and executive succession strategies, all of which were related to satisfaction with the strategy at the institution. Satisfaction with strategy for respondents dissatisfied with funding for internationalization was influenced by effective executive succession and coordination strategies, such as retention of senior university leadership and communication with faculty and support from senior administration. As scholarship highlights, international offices at less well-resourced institutions must adapt to better align with the environment in a fiscally constrained environment (Green et al., 2012). Merger strategies, such as the effective management of interorganizational dependencies through outsourcing of university functions, and the perception of the relative strength of their organization within the market, impacted this group's satisfaction with their institution's strategy for internationalization. 
Second, executive succession - but not acquisition or merger strategies - had a significant relationship with a sense of strategy for respondents who were moderately satisfied with their institution's funding for internationalization, although to less of an extent than respondents who were dissatisfied with funding levels. Executive succession is particularly important in a resource scarce environment (Welsh \& Dehler, 1988); thus, it is not surprising that retention of senior university leadership, communication with faculty, and support from senior administration were among top factors with the strongest relationship with satisfaction with their institution's strategy for internationalization for Group 1 and Group 2 alike. The key difference between Group 1 and Group 2 respondents, however, was that satisfaction with the strategy for internationalization for Group 2 respondents was not dependent on merger behaviors at all (e.g., outsourcing and market niche) and influenced much more by retention of senior university leadership. Communication with faculty and support from senior administration were equally important for both groups. Pfeffer and Salancik (1978) argue that executive succession is an organization's internally focused response to dependences on human and financial resources in an unpredictable fiscal environment. Institutions with more dependence on these external resources have greater turnover (Harrison, Torres, \& Kukalis, 1988); thus, institutions that maintain consistent leadership are more likely to be viewed as having a strategy — despite concerns about funding - than ones where ever-changing senior leadership reflects the ever-changing, competitive, and uncertain economic environment.

Finally, support from senior administration, an executive succession factor, had a significant relationship with a sense of strategy for respondents with high-levels of satisfaction with funding for internationalization. It is noteworthy that support from senior administration had the largest influence by far for all three groups. This result suggests that support from senior administration is the sine qua non for satisfaction with an institution's internationalization strategy. The results further suggest that support from senior administration is essential for all institutions, as senior administrators determine - or, at least, heavily influence - the allocation of existing resources and structural supports at an institution. Well-resourced institutions have fewer interorganizational or intraorganizational dependencies that impact satisfaction with the institution's strategy for internationalization. In contrast, less-resourced institutions are more dependent on a variety of factors being in place. For example, retention of senior university leadership and communication with faculty are important factors in effective management of dependencies in all organizations. However, while these factors are sufficient for satisfaction with the strategy for internationalization for respondents with high-levels of satisfaction with funding, they are essential for respondents with low- and moderate-levels of satisfaction with funding. Moreover, these factors have an outsized influence at institutions where staff have greater concerns about funding for internationalization, such as they collectively account for fully one third of satisfaction with the internationalization strategy, whereas, they account for just over one fifth of satisfaction with the internationalization strategy where staff are satisfied with funding. This research confirmed that educational and entrepreneurial rationales for international education coexist (Knight, 2004; Williams \& Kitaev, 2005), and international 
educators' satisfaction with perceptions of organizational strategy is a useful proxy to how they negotiate the human and financial dependences of these coexisting rationales. The results of this study suggest this negotiation is far more complex-and dependent on far more factors - at institutions where international educators perceive fewer human and financial resources to be available.

These results have significant implications for practice. Internationalization entails stronger connections between HEIs and the marketplace, and entrepreneurialism is often a key driver of internationalization (Altbach \& Knight, 2007; Slaughter \& Cantwell, 2011), especially for less-resourced institutions (ACE, 2012). Revenue generation is a consideration for all types of activities - from how institutions recruit international students, sponsor study abroad program, and internationalize their curriculum - and evaluating the benefit of new initiatives and partnerships. In this study, we investigated the coexistence of various institutional strategies at institutions with more and less dependence on revenue generation for support of internationalization efforts. Logistically, while the ever-closer relationship between HEIs and private market-driven companies may be driven by economic necessity, how these relationships are managed is of critical importance. International educators who are dissatisfied with how their institutions outsource services are more likely to sense a lack of strategy for internationalization. Likewise, international educators who do not perceive a strong rationale that provides a strategic focus or niche to internationalization initiatives are more likely to sense that internationalization efforts are adrift. Thus, institutions must develop clear criteria for identifying for external partners that demonstrate alignment with rationales for internationalization, high ethical standards, and alignment with strategic emphasis in areas such as student mobility, geographic location, or thematic areas of faculty research.

\section{Limitations and Further Research}

A few limitations must be considered when interpreting the results of this study. This research was based on the results of a survey of individuals; thus, the questionnaire items to investigate international funding and strategies were limited. The data did not contain objective measures of institutional finances or internationalization budgets. Therefore, the study relied on respondents' rated satisfaction with their institution's funding as a proxy for the extent of resourced institutions. Despite this limitation, individual satisfaction has long been used to determine institutional quality in higher education research (e.g., Aitken, 1982; Astin, 1984). Furthermore, it could be argued that perceptions about funding - not just budgetary data —influence human behavior, much like consumer sentiment-not just economic data - about the economy influences economic behavior. Finally, the importance of executive succession in the findings suggests that further research in executive succession, professional development, and stakeholder management might be a constructive frame of reference for further research in this area.

\section{Declaration of Conflicting Interests}

The author(s) declared no potential conflicts of interest with respect to the research, authorship, and/or publication of this article. 


\section{Funding}

The author(s) received no financial support for the research, authorship, and/or publication of this article.

\section{ORCID iD}

Jenny J. Lee (iD https://orcid.org/0000-0003-2799-487X

\section{References}

Agresti, A., \& Finlay, B. (2009). Statistical methods for the social sciences (4th ed.). Upper Saddle River, NJ: Prentice Hall.

Aitken, N. D. (1982). College student performance, satisfaction and retention: Specification and estimation of a structural model. The Journal of Higher Education, 53, 32-50.

Altbach, P. G., \& Knight, J. (2007). The internationalization of higher education: Motivations and realities. Journal of Studies in International Education, 11, 290-305.

American Association of Collegiate Registrars and Admissions Officers. (2017). Trending topics survey: International applicants for fall 2017-Institutional \& applicant perceptions. Washington, DC: Author. Retrieved from www.aacrao.org/docs/default-source/ TrendTopic/Immigration/final-report.pdf

American Council on Education. (2012). Mapping internationalization on U.S. Campuses. Washington, DC: Author.

Astin, A. W. (1984). Student involvement: A developmental theory for higher education. Journal of College Student Personnel, 25, 297-308.

Bound, J., Braga, B., Khanna, G., \& Turner, S. (2016). A passage to America: University funding and international students. Population Studies Center, University of Michigan. Retrieved from http://www.psc.isr.umich.edu/pubs/pdf/rr16-859.pdf

Cantwell, B. (2015). Are international students cash cows? Examining the relationship between new international undergraduate enrollments and institutional revenue at public colleges and universities in the U.S. Journal of International Students, 5, 512-525.

Casciaro, T., \& Piskorski, M. J. (2005). Power imbalance, mutual dependence, and constraint absorption: A closer look at Resource Dependence Theory. Administrative Science Quarterly, 50, 167-199.

Cox, D. R., \& Snell, E. J. (1989). Analysis of binary data (Vol. 32). Boca Raton, FL: CRC Press.

Deschamps, E., \& Lee, J. J. (2015). Internationalization as mergers and acquisitions: Senior International Officers' entrepreneurial strategies and activities in public universities. Journal of Studies in International Education, 19, 122-139. doi:10.1177/1028315314538284

Glass, C. R., \& Matherly, C. (2015, September). Building trust to advance international education through appreciative inquiry. IIE Networker, pp. 20-21.

Green, M. F., Marmolejo, F., \& Egron-Polak, E. (2012). The internationalization of higher education. In D. K. Deardorff, H. de Wit, J. D. Heyl, \& T. Adams (Eds.), The SAGE handbook of international higher education (pp. 439-456). Thousand Oaks, CA: Sage.

Harrison, J. R., Torres, D. L., \& Kukalis, S. (1988). The changing of the guard: Turnover and structural change in the top-management positions. Administrative Science Quarterly, 33, 211-232.

Hillman, A. J., Withers, M. C., \& Collins, B. J. (2009). Resource dependence theory: A review. Journal of Management, 35(6), 1404-1427.

Institute for International Education. (2016). Open Doors ${ }^{\circledR} 2016$ : Report on international educational exchange. Washington, DC: Author. 
Knight, J. (2004). Internationalization remodeled: Definition, approaches, and rationales. Journal of Studies in International Education, 8, 5-31.

Lee, J. J. (2017, April 7). Who is the "public" in higher education today? Inside Higher Ed. Retrieved from https://www.insidehighered.com/views/2017/04/07/academe-needs-broadenits-concept-public-good-essay

Ott, R. L., \& Longnecker, M. (2001). Statistical methods and data analysis (5th ed.). Pacific Grove, CA: Duxbury.

Pfeffer, J. (1987). A resource dependence perspective on interorganizational relations. In M. S. Mizruchi \& M. Schwartz (Eds.), Intercorporate relations: The structural analysis of business (pp. 22-55). Cambridge, UK: Cambridge University Press.

Pfeffer, J., \& Salancik, G. R. (1978). The external control of organizations: A resource dependence perspective. New York, NY: Harper \& Row.

Redden, E. (2017, March 13). Will international students stay away? Inside Higher Ed. Retrieved from https://www.insidehighered.com/news/2017/03/13/nearly-4-10-universities-reportdrops-international-student-applications

Slaughter, S., \& Cantwell, B. (2011). Transatlantic moves to the market: The United States and the European Union. Higher Education, 63, 583-606. doi:10.1007/s10734-011-9460-9

Welsh, M. A., \& Dehler, G. E. (1988). Political legacy of administrative succession. Academy of Management Journal, 31, 948-961.

Williams, G., \& Kitaev, I. (2005). Overview of national policy contexts for entrepreneurialism in higher education institutions. Higher Education Management and Policy, 17, 125-141.

\section{Author Biographies}

Chris R. Glass is an assistant professor in the Department of Educational Foundations \& Leadership at Old Dominion University. His research focuses on international student engagement at U.S. colleges and universities, as well the actions that have enabled colleges and universities to create more inclusive campus environments for international students.

Jenny J. Lee is a professor at the Center for the Study of Higher Education at the University of Arizona. Her research has examined organizational cultures and the underlying influences. 